\title{
Coumarins and Alkaloids from the Stems of Metrodorea Flavida
}

\author{
Ana Cristina S. Baetas, Mara S.P. Arruda*, Adolfo H. Müller, \\ and Alberto C. Arruda
}

\author{
Departamento de Química, CCEN, Campus Universitário,
} Universidade Federal do Pará, 66075-900 Belém - PA, Brazil

\begin{abstract}
Uma nova cumarina , a 5,6-metilenodioxi-7,8-dimetoxicumarina, foi isolada a partir dos galhos de Metrodorea flavida, juntamente com outras cumarinas e alcalóides conhecidos. As estruturas das substâncias isoladas foram definidas por análises de seus dados espectrais, bem como por comparação com dados da literatura.
\end{abstract}

A new coumarin, 5,6-methylenedioxy-7,8-dimethoxycoumarin has been isolated from the stems of Metrodorea flavida, as well as known coumarins and alkaloids. The structures of the new and the known compounds were established by spectral data and by comparison with the literature data.

Keywords: Metrodorea flavida, Rutaceae, coumarins, alkaloids

\section{Introduction}

In a previous paper, we reported the characterization of a new coumarin, 8-(2,3-dihydroxy-3-methylbutyloxy)-6,7methylenedioxycoumarin, together with known furocoumarins and a furofuran lignan, which were isolated from the leaves of Metrodorea flavida ${ }^{1}$. In continuation of our phytochemical studies on the constituents of this species, we report from the stem the isolation and structural elucidation of a new coumarin 5,6-methylenedioxy-7,8-dimethoxycoumarin (1), in addition to the known compounds: scoparone $(2)^{2} ; 6,7-$ methylenedioxy-8methoxycoumarin $(3)^{3}$; xanthotoxin $(4)^{4}$; isopimpinellin $(5)^{4}$; imperatorin $(6)^{4}$; braylin $(7)^{5} ; \gamma$-fagarine $(8)^{6}$; kokusaginine $(\mathbf{9})^{7}$; maculin $(\mathbf{1 0})^{8}$; syringic aldehyde $(\mathbf{1 1})^{9}$; rutaecarpine $(\mathbf{1 2})^{10}$; sitosterol and lupeol.

All the compounds were isolated by chromatographic techniques. The structural elucidation of these compounds were based on spectrometric data, especially IR, ${ }^{1} \mathrm{H}$ NMR and ${ }^{13} \mathrm{C} \mathrm{NMR}$, involving comparison with the literature data.

\section{Experimental}

\section{Equipment}

Mps uncorr. IR were recorded in $\mathrm{KBr}$ discs. ${ }^{1} \mathrm{H}$ and ${ }^{13} \mathrm{C}$-NMR spectra were recorded at 300 and $75 \mathrm{MHz}$, respectively, in $\mathrm{CDCl}_{3}$ on a Varian GEMINI 300 instrument and at 400 and $100 \mathrm{MHz}$, in DMSO, on a Brucker
ARX 400 instrument. EIMS were obtained by direct probe insertion at $70 \mathrm{eV}$.

\section{Plant material}

Metrodorea flavida was collected in Paragominas, State of Pará, Brazil, in December 1991. A voucher specimen is deposited at the Herbarium of the CPATU-EMBRAPA, Belém, Brazil.

\section{Extraction and isolation}

After drying, stems (231 g) were ground and percolated with hexane and $\mathrm{CH}_{2} \mathrm{Cl}_{2}$, successively. The concd. hexane extract $(3.5 \mathrm{~g})$ was submitted to $\mathrm{CC}$ using silica gel 60 Merck (particula size 0.063-0.200 mm) packed in hexane. Elution was performed with a gradient of hexane, $\mathrm{Me}_{2} \mathrm{CO}$ and $\mathrm{MeOH}$, affording 22 frs. The frs 3 and 7 after prep. TLC (silica gel and hexane- $\mathrm{CH}_{2} \mathrm{Cl}_{2}-\mathrm{MeOH} / 10: 10: 0.1$ ) yielded lupeol and sitosterol, respectively.

Fr. 12 was rechromatographed on silica gel using gradients of hexane, $\mathrm{CH}_{2} \mathrm{Cl}_{2}$ and $\mathrm{MeOH}$. Those frs. containing homogeneous components, as judged by TLC, were combined and the solvent removed. Frs. 12/9-12 and 12/14-17 subjected to prep. TLC on silica gel (hexane- $\mathrm{Me}_{2} \mathrm{CO} /$ 75:25) afforded $\mathbf{6}(31.4 \mathrm{mg})$ and $\mathbf{1 2}(7.5 \mathrm{mg})$, respectively. Fr.17 was subjected to $\mathrm{CC}$ on silica gel eluting with gradients of hexane, $\mathrm{CH}_{2} \mathrm{Cl}_{2}, \mathrm{Me}_{2} \mathrm{CO}$ and $\mathrm{MeOH}$ affording 9 (3.1 mg).

The $\mathrm{CH}_{2} \mathrm{Cl}_{2}$ extract (4.2 g) was subjected to chromatographic treatments similar to those used for the hexane 
<smiles>[R]c1c([R])c([R])c2oc(=O)ccc2c1[R]</smiles><smiles>[R]c1c2ccc(=O)oc2c([R])c2ccoc12</smiles>
$1 \begin{aligned} & \mathrm{R}_{1}-\mathrm{R}_{2}=\mathrm{OCH}_{2} \mathrm{O}, \\ & \mathrm{R}_{3}=\mathrm{R}_{4}=\mathrm{OCH}_{3}\end{aligned}$

1a $\mathrm{R}_{1}=\mathrm{R}_{4}=\mathrm{OCH}_{3}$, $\mathrm{R}_{2}-\mathrm{R}_{3}=\mathrm{OCH}_{2} \mathrm{O}$

1b $\mathrm{R}_{1}=\mathrm{R}_{2}=\mathrm{OCH}_{3}$, $\mathrm{R}_{3}-\mathrm{R}_{4}=\mathrm{OCH}_{2} \mathrm{O}$

$2 \mathrm{R}_{1}=\mathrm{R}_{4}=\mathrm{H}$, $\mathrm{R}_{2}=\mathrm{R}_{3}=\mathrm{OCH}_{3}$

$3 \mathrm{R}_{1}=\mathrm{H}$, $\mathrm{R}_{2}-\mathrm{R}_{3}=\mathrm{OCH}_{2} \mathrm{O}$, $\mathrm{R}_{4}=\mathrm{OMe}$<smiles>COc1cc2ccc(=O)oc2c2c1OC(C)(C)C=C2</smiles><smiles>[R]c1cc2c(OC)c3ccoc3nc2c([R])c1[R]</smiles>
$8 \mathrm{R}_{1}=\mathrm{R}_{2}=\mathrm{H}, \mathrm{R}_{3}=\mathrm{OMe}$ $9 \mathrm{R}_{1}=\mathrm{R}_{2}=\mathrm{OMe}, \mathrm{R}_{3}=\mathrm{H}$ $10 \mathrm{R}_{1}-\mathrm{R}_{2}=\mathrm{OCH}_{2} \mathrm{O}, \mathrm{R}_{3}=\mathrm{H}$<smiles>O=c1c2ccccc2nc2n1CCc1c-2[nH]c2ccccc12</smiles><smiles>COc1cc(C=O)cc(OC)c1O</smiles>

11

extract. Frs. 4-5 afforded a mixture $(6.3 \mathrm{mg})$ of lupeol and sitosterol. The Fr. 7 afforded 6 ( $4.8 \mathrm{mg}$ ). Fr. 8 was rechromatographed on silica gel using gradients of hexane, $\mathrm{Me}_{2} \mathrm{CO}$ and $\mathrm{MeOH}$ yielding $4(3.7 \mathrm{mg}), 6(8.1 \mathrm{mg}), 7$ $(5.2 \mathrm{mg})$ and $12(1.3 \mathrm{mg})$. Fr. 9 was subjected to $\mathrm{CC}$ on silica gel using hexane, $\mathrm{Me}_{2} \mathrm{CO}$ and $\mathrm{MeOH}$ at different ratios of increasing polarity to give $7.0 \mathrm{mg}$ of the new coumarin $\mathbf{1}, \mathbf{2}(2.7 \mathrm{mg}), \mathbf{3}(0.5 \mathrm{mg}), \mathbf{4}(6.3 \mathrm{mg}), \mathbf{5}(4.3 \mathrm{mg})$, $\mathbf{8}(2.3 \mathrm{mg}), \mathbf{1 0}(3.2 \mathrm{mg}), \mathbf{1 1}(2.4 \mathrm{mg})$ and $\mathbf{1 2}(1.4 \mathrm{mg})$.

5,6-Methylenedioxy-7,8-dimetoxycoumarin (1). Amorphous solid. ${ }^{1} \mathrm{H}$ and ${ }^{13} \mathrm{C}-\mathrm{NMR}$ : see Table 1 .

\section{Results and Discussion}

The new coumarin 1 was obtained from the dichloromethane extract of M. flavida and showed as a blue
Table 1. NMR data for compound $1\left(\mathrm{CDCl}_{3}, J\right.$ values, in $\mathrm{Hz}$, are given in parentheses).

\begin{tabular}{lccc}
\hline Position & ${ }^{13} \mathrm{C}$ & ${ }^{1} \mathrm{H}$ & $\mathrm{COLOC}$ \\
\hline 2 & 160.5 & & $\mathrm{H}-4$ \\
3 & 112.0 & $6.20, d(9.7)$ & \\
4 & 138.8 & $7.91, d(9.7)$ & \\
$4 \mathrm{a}$ & 107.0 & & $\mathrm{H}-3$ \\
5 & 142.9 & & $\mathrm{OCH}_{2} \mathrm{O}$ \\
6 & 132.8 & & $\mathrm{OCH}_{2} \mathrm{O}$ \\
7 & 133.4 & & $\mathrm{MeO}^{-7}$ \\
8 & 126.9 & & $\mathrm{MeO}-8$ \\
$8 \mathrm{a}$ & 143.7 & & $\mathrm{H}-4$ \\
$7-\mathrm{OMe}$ & 61.1 & $4.04, s$ & \\
$8-\mathrm{OMe}^{-}$ & 61.1 & $3.99, s$ & \\
$\mathrm{OCH}_{2} \mathrm{O}$ & 102.1 & $6.01, s$ & \\
\hline
\end{tabular}

Hydrogens correlating with carbon resonance.

color on TLC under UV light $336 \mathrm{~nm}$. Its ${ }^{1} \mathrm{H}$ NMR spectrum exhibited resonances typical of $\mathrm{H}-3$ and $\mathrm{H}-4(\delta 6.20$ and 7.91) of the coumarin nucleus in which $\mathrm{C}-5$ was oxygenated ${ }^{11}$. The presence of a methylenedioxy group was indicated from the methylene hydrogens signal at $\delta$ $6.01(s)$ and two methoxy groups from the signals at $\delta$ 4.04 and 3.99 ( $s, 3 \mathrm{H}$ each one). These groups were located at the positions $5,6,7$ and 8 suggesting one of the possible structures $\mathbf{1}, \mathbf{1 a}$ or $\mathbf{1 b}$. Further information concerning the actual positions of the methoxy groups was obtained by analysis of the 1D-NOE difference spectrum. Irradiation of the signal at $\delta 7.91(d, \mathrm{H}-4)$ didn't enhance the signals at $\delta 4.04$ and 3.99 (2x OMe), which confirmed the placement of the methylenedioxy group at C-5/C-6. This result is consistent with the structure 1 . The assignments of the signals of carbons 3,4 and $-\mathrm{OCH}_{2} \mathrm{O}$ - moiety in the ${ }^{13} \mathrm{C}-\mathrm{NMR}$ spectrum were established by HETCOR $\left({ }^{13} \mathrm{C},{ }^{1} \mathrm{H}-\mathrm{COSY}-{ }^{1} \mathrm{~J}_{\mathrm{CH}}\right)$ spectrum and the attribution of the quaternary carbons was made by COLOC $\left({ }^{13} \mathrm{C},{ }^{1} \mathrm{H}-\mathrm{COSY}-{ }^{n} \mathrm{~J}_{\mathrm{CH}}, \mathrm{n}=2\right.$ and 3) experiment (Table 1).

This is the first report of the occurrence of one indolopiridoquinazoline alkaloid (rutaecarpine) from the genus Metrodorea. This fact reinforces the taxonomic position of the Metrodorea flavida into the Cusparieae tribe, due to the occurrence of this type of alkaloid in the tribes Cusparieae and Xanthoxyleae.

\section{Acknowledgements}

The authors are grateful to Coordenação de Aperfeiçoamento de Pessoal de Ensino Superior (CAPES) and Financiadora de Estudos e Projetos (FINEP) for financial 
support and to Universidade Federal de São Carlos (São Carlos - São Paulo, Brazil) for ${ }^{1} \mathrm{H}$ and ${ }^{13} \mathrm{C}-\mathrm{NMR}$ spectra at 400 and $100 \mathrm{MHz}$, respectively.

\section{References}

1. Baetas, A.C.; Arruda, M.S.P.; Müller, A.H.; Arruda, A.C. Phytochemistry 1996, 43, 491.

2. Adegosam, E.K. Phytochemistry 1973, 12, 2310.

3. Sarker, S.D.; Gray, A.I.; Waterman, P.G. J. Nat.Prod. 1994, 57, 1549.

4. Razdam, T.K.; Qadri, B.; Harkar, S.; Waight, E. Phytochemistry 1987, 27, 2063.

5. Silva, M.; Cruz, M.A. Phytochemistry 1971, 10, 3255.
6. Tillequin, F.; Koch, M.; Sevenet, T.H. Planta Medica 1980, 38, 3830.

7. Khalid, S.A.; Waterman, P.G. Phytochemistry 1981, 20, 2761.

8. Dreyer, D.L. Phytochemistry 1980, 19, 941.

9. Pouchert, C.J. In The Aldrich Library of NMR Spectra, 2nd ed, Aldrich Chemical Company Inc., USA, 1983, vol. 2, p 179.

10. Breitmaier, E.; Voelter, W. In Carbon-13 NMR Spectroscopy, 3rd ed., UCH, Weinheim, 1987, p 447.

11. Murray, R.D.H.; Mendez, J.; Brown, S.A. In The Natural Coumarins: Ocurrence, Chemistry and Biochemistry, John Wiley \& Sons Ltd, New York, 1982, p 21.

Received: September 9, 1998 